\title{
MEWUJUDKAN GOOD GOVERNANCE DI PEMERINTAH KOTA MALANG MELALUI IMPLEMENTASI UNDANG-UNDANG NO. 14 TAHUN 2008 TENTANG KETERBUKAAN INFORMASI PUBLIK
}

\author{
Kurniawan Muhammad \\ Mahasiswa Program Doktor Ilmu Administrasi, Fakultas Ilmu Administrasi \\ Universitas Brawijaya \\ Email: abushindid73@gmail.com
}

\begin{abstract}
Transparency is the most important part of governance, particularly an important part of the global governance agenda. In the context of governance in Indonesia, the spirit of communicating public information openly by every level of government is very strong. The process of openness is delivered through online media such as websites. But in its implementation, the implementation of public information disclosure mandated by Law no. 14 of 2008 on Public Information Openness has not appeared consistent.
\end{abstract}

Keyword: Good Governance; Public Information Openness; Transparency; Accountability; Policy.

\section{PENDAHULUAN}

Pada era tahun 1990-an, ketika terjadi demokratisasi di dunia, muncul cara pandang baru terhadap pemerintahan. Yakni ditandai dengan munculnya istilah governance dan good governance yang diperkenalkan oleh lembaga donor seperti IMF dan World Bank. Perspektif yang berpusat pada government bergeser ke perspektif governance.

Government, lebih bersifat tertutup dan tidak sukarela. Juga tidak dilibatkan swasta (private) dalam membentuk struktur keorganisasiannya. Sedangkan governance melibatkan seluruh aktor, baik publik maupun private (swasta) dalam membentuk struktur sehingga bisa menempatkan pengarutan kebijakan sesuai kebutuhan fungsionalitasnya.
Dengan bergesernya paradigma dari government ke arah governance, yang menekankan pada kolaborasi dalam kesetaraan dan keseimbangan antara pemerintah, sektor swasta, dan masyarakat madani (civil society), maka dikembangkan pandangan atau paradigma baru administrasi publik yang disebut dengan kepemerintahan yang baik (good governance).

Good governance mengandung arti hubungan yang sinergis dan konstruktif di antara negara, sektor swasta dan masyarakat (society). Dalam hal ini adalah kepemerintahan yang mengembangkan dan menerapkan prinsip-prinsip professional, akuntabilitas, transparansi, pelayanan prima, demokrasi, efisiensi, efektivitas, supremasi hukum, dan dapat diterima oleh seluruh masyarakat. 
Menurut United National Development Program (UNDP) ada 14 prinsip good governance. Yaitu: Pertama, wawasan ke depan (visionary). Kedua, keterbukaan dan transparansi (openness and transparency). Ketiga, partisipasi masyarakat (participation). Keempat, tanggung gugat (accountability). Kelima, supremasi hukum (rule of law). Keenam, demokrasi (democracy). Ketujuh, profesionalisme dan kompetensi (profesionalism and competency). Kedelapan, daya tanggap (responsiveness). Kesembilan, keefisienan dan keefektifan (efficiency and effectiveness). Kesepuluh, desentralisasi (decentralization). Kesebelas, kemitraan dengan dunia usaha swasta dan masyarakat (private sector and civil society partnership). Keduabelas, komitmen pada pengurangan kesenjangan (commitment to reduce Inequality). Ketigabelas, komitmen pada lingkungan hidup (commitment to environmental protection). Dan keempatbelas, komitmen pasar yang fair (commitment to fair market).

Di antara 14 prinsip dalam good governance menurut UNDP itu, salah satu yang sangat penting adalah keterbukaan dan transparansi. Transparansi adalah keterbukaan atas semua tindakan dan kebijakan yang diambil oleh pemerintah. Prinsip transparansi menciptakan kepercayaan timbal-balik antara pemerintah dan masyarakat melalui penyediaan informasi dan menjamin kemudahan di dalam memperoleh informasi yang akurat dan memadai. Tranparansi dibangun atas dasar arus informasi yang bebas. Seluruh proses pemerintahan, lembaga-lembaga dan informasi perlu dapat diakses oleh pihakpihak yang berkepentingan, dan informasi yang tersedia harus memadai agar dapat dimengerti dan dipantau. Sehingga bertambahnya wawasan dan pengetahuan masyarakat terhadap penyelenggaraan pemerintahan.Meningkatnya kepercayaan masyarakat terhadap pemerintahan, meningkatnya jumlah masyarakat yang berpartisipasi dalam pembangunan dan berkurangnya pelanggaran terhadap peraturan perUndang-undangan.

Di Indonesia, untuk menjalankan prinsip transparansi dan keterbukaan ini dikeluarkanlah Undang-undang No 14 tahun 2008 tentang Keterbukaan Informasi Publik.Ini adalah salah satu produk hukum Indonesia yang dikeluarkan pada 2008 dan diundangkan pada 30 April 2008, dan mulai berlaku dua tahun setelah diundangkan. Undang-undang yang terdiri dari 64 pasal ini pada intinya memberikan kewajiban kepada setiap Badan Publik untuk membuka akses bagi setiap pemohon informasi publik untuk mendapatkan informasi publik, kecuali beberapa informasi tertentu.

Sebelum diterbitkannya Undangundang No 14 tahun 2008, hak warga untuk mengetahui apa yang terjadi dalam suatu birokrasi publik seringkali masih sangat terbatas. Apalagi untuk memperoleh informasi tertentu yang bersifat agak sensitif (karena terkait dengan kepentingan pejabatnya), misalnya anggaran untuk proyek-proyek di suatu birokrasi, warga pada umumnya tidak memiliki akses sama sekali (Dwiyanto 2005: 225). Sehingga dengan demikian, transparansi menjadi barang mewah sehingga tidak semua orang dapat menikmatinya. Padahal transparansi menjadi salah satu ukuran penting dari good 
governance. Governance dinilai baik atau buruk, salah satunya ditentukan oleh tingkat transparansi di dalam pemerintahannya (Dwiyanto 2005: 226). Prinsip transparansi tidak hanya harus dilaksanakan oleh pemerintah pusat. Tapi, di tingkat pemerintah daerah, prinsip transparansi juga harus dilaksanakan.

Pemerintah daerah juga harus menjalankan prinsip transparansi melalui pelaksanaan Undang-Undang No 14 tahun 2008 tentang Keterbukaan Informasi Publik. Berangkat dari hal ini, penulis ingin lebih jauh melihat dan mengamati tentang bagaimana implementasi Undang-Undang No 14 tahun 2008 tersebut di Kota Malang. Dan Kota Malang merupakan kota terbesar kedua di Jawa Timur setelah Surabaya. Sebagai kota terbesar kedua di Jawa Timur, tentu Kota Malang tergolong sebagai kota yang sangat dinamis dengan berbagai macam persoalan publik yang mengemuka. Karena itu, penelitian ini penting dilakukan sebagai parameter bagi sebuah proses transparansi, khususnya untuk mengetahui bagaimana prinsip-prinsip good governance dilaksanakan di daerah.

Dari paparan diatas, tulisan ini akan mendiskusikan beberapa hal yakni: Pertama, penerapan Undang-Undang No 14 tahun 2008 tentang Keterbukaan Informasi Publik (KIP) yang dilaksanakan oleh Pemerintah Kota Malang sebagaimana yang telah diatur dalam diatur pada pasal 2 Undang-Undang No. 14 tahun 2008 tentang KIP. Kedua, Apakah informasi publik yang disampaikan kepada masyarakat oleh Pemerintah Kota Malang sudah sesuai dengan pasal 9 UndangUndang N0 14 tahun 2008. Ketiga, Bagaimana
APBD dapat diakses dan diawasi oleh publik, dengan mengacu pada pasal 11 UndangUndang No. 14 tahun 2008.

\section{GOVERNANCE DAN KETERBUKAAN INFORMASI PUBLIK DALAM PANDANGAN TEORITIK}

Menurut Kooiman (2009: 273),

governance merupakan serangkaian proses interaksi sosial politik antara pemerintah dengan masyarakat dalam berbagai bidang yang berkaitan dengan kepentingan masyarakat dan intervensi pemerintah atas kepentingan-kepentingan tersebut. Governance merupakan mekanisme-mekanisme, prosesproses dan institusi-institusi melalui warga negara mengartikulasi kepentingankepentingan mereka, memediasi perbedaanperbedaan mereka serta menggunakan hak dan kewajiban legal mereka. Governance merupakan proses lembaga-lembaga pelayanan, mengelola sumber daya public dan menjamin realita hak asasi manusia. Dalam konteks ini good governance memiliki hakikat yang sesuai yaitu bebas dari penyalahgunaan wewenang dan korupsi, serta dengan pengakuan hak yang berlandaskan pada pemerintahan hukum.

Pierre Landell-Mills dan Ismael Seregeldin mendefinisikan good governance sebagai penggunaan otoritas politik dan kekuasaan untuk mengelola sumber daya demi pembangunan sosial ekonomi. Sedangkan Robert Charlick mengartikan good governance sebagai pengelolaan segala macam urusan publik secara efektif melalui pembuatan peraturan dan/atau kebijakan yang absah demi untuk mempromosikan nilai-nilai kemasyarakatan. 
Seperti disampaikan Bob Sugeng Hadiwinata, asumsi dasar good governance haruslah menciptakan sinergi antara sektor pemerintah (menyediakan perangkat aturan dan kebijakan), sektor bisnis (menggerakkan roda perekonomian), dan sektor civil society (aktivitas swadaya guna mengembangkan produktivitas ekonomi, efektivitas dam efisiensi).

Syarat bagi terciptanya good governance, yang merupakan prinsip dasar, meliputi partisipatoris, rule of law (penegakan hukum), transparansi, responsiveness (daya tanggap), konsensus, persamaan hak, efektiviras, dan efisiensi, dan akuntabilitas.

Partisipatoris artinya, setiap pembuatan peraturan dan/atau kebijakan selalu melibatkan unsur masyarakat (melalui wakil-wakilnya). Rule of Law artinya, harus ada perangkat hukum yang menindak para pelanggar, menjamin perlindungan HAM (Hak Asasi Manusia), tidak memihak, dan berlaku pada semua warga. Responsiveness, artinya lembaga publik harus mampu merespon kebutuhan masyarakat, terutama yang berkaitan dengan basic needs (kebutuhan dasar) dan HAM (hak sipil, hak politik, hak ekonomi, hak sosial, dan hak budaya). Konsensus, artinya jika ada perbedaan kepentingan yang mendasar di dalam masyarakat, penyelesaian harus mengutamakan cara dialog/musyawarah menjadi konsensus. Persamaan hak, artinya pemerintah harus menjamin bahwa semua pihak, tanpa terkecuali, dilibatkan di dalam proses politik, tanpa ada satu pihak pun yang dikesampingkan. Efektivitas dan Efisiensi, artinya pemerintah harus efektif (absah) dan efisien dalam memproduksi output berupa aturan, kebijakan, pengelolaan keuangan negara, dan lain-lain. Akuntabilitas, artinya suatu perwujudan kewajiban dari suatu instansi pemerintahan untuk mempertanggungjawabkan keberhasilan dan kegagalan pelaksanaan misinya. Terakhir adalah transparansi. Ini lah salah satu yang terpenting dari prinsip good governance. Transparansi berarti adanya ruang kebebasan untuk memperoleh informasi publik bagi warga yang membutuhkan (diatur oleh Undang-undang). Ada ketegasan antara rahasia negara dengan informasi yang terbuka untuk public (Santosa 2012: 131).

Transparansi merupakan konsep yang sangat penting dan menjadi semakin penting sejalan dengan semakin kuatnya keinginan untuk mengembangkan praktik good governance. Praktik good governance mensyaratkan adanya transparansi dalam proses penyelenggaraan pemerintahan secara keseluruhan. Pemerintah dituntut untuk terbuka dan menjamin akses stakeholders terhadap berbagai informasi mengenai proses kebijakan publik, alokasi anggaran untuk pelaksanaan kebijakan, serta pemantauan dan evaluasi terhadap pelaksanaan kebijakan. (Dwiyanto, 2014: 223).

Informasi mengenai tindakan pemerintah, misalnya, alasan yang melatarbelakangi tindakan, bentuk tindakan serta waktu dan cara melakukan tindakan, harus tersedia bagi stakeholders dan masyarakat luas. Dengan memiliki akses terhadap berbagai jenis informasi semacam itu, maka masyarakat dan stakeholders dapat menilai apakah pemerintah telah benar-benar mengabdi pada kepentingan masyarakat atau kepentingan pihak lain. Masyarakat dan 
stakeholders dapat menilai sejauh mana keberpihakan pemerintah terhadap kepentingan mereka dan menentukan sikap yang tepat dalam merespon kebijakan dari pemerintah tersebut (Dwiyanto, 2014: 223).

Dengan memberikan kesempatan kepada masyarakat luas untuk mengetahui berbagai informasi mengenai penyelenggaraan pemerintahan, maka dapat mempermudah upaya masyarakat dalam menilai keberpihakan pemerintah terhadap kepentingan publik. Masyarakat secara mudah dapat menentukan apakah akan memberikan dukungan kepada pemerintah, atau sebaliknya, kritik dan protes perlu dilakukan agar pemerintah lebih berpihak kepada kepentingan publik. Lebih dari itu, hak untuk memperoleh informasi adalah hak asasi dari setiap warga negara agar dapat melakukan penilaian terhadap kinerja pemerintah secara tepat (Dwiyanto, 2014: 224).

Di dalam menjalankan prinsip transparansi, perlu adanya partisipasi. Partisipasi merupakan hal utama dalam implementasi kebijakan. Salah satu tipe atau jenis dari partisipasi adalah sharing informasi. (Brinkerhoff, 2002 : 65). Sharing informasi adalah arus komunikasi searah. Dilakukan agar aktor kebijakan selalu mendapatkan informasi, menjaga transparansi dan membangun legitimasi. Dari pemerintah ke masyarakat, contoh penyebaran dokumen resmi melalui surat kabar, majalah, radio, TV, hingga laman dan lain-lain. Sebaliknya dari masyarakat ke pemerintah dilakukan dalam wujud merespon setiap survey, kuisioner, akses telepon bebas pulsa, dan menyediakan beragam data opini dan analisis.

Di Indonesia, untuk merespon adanya tuntutan bahwa pemerintah harus menjalankan prinsip transparansi sebagai syarat bagi terwujudnya good governance, diterbitkan lah Undang-undang No 14 tahun 2008 tentang Keterbukaan Informasi Publik. Menurut Rajamuddin dalam Jurnal Al Risalah menyebutkan, di Indonesia, hadirnya Undang-Undang No 14 tahun 2008 yang disahkan pada 3 April 2008 adalah capaian positif untuk mendorong terwujudnya good governance. Dengan demikian, Indonesia telah mencatatkan diri sebagai negara kelima di Asia, dan ke-76 di dunia yang secara resmi mengadopsi prinsip-prinsip keterbukaan informasi publik.

Secara substansi, seperti yang ditulis oleh Rajamuddin, Undang-Undang No 14 tahun 2008 tentang Keterbukaan Informasi Publik memuat dan berhubungan dengan: Pertama, Undang-Undang Keterbukaan Informasi Publik adalah Undang-undang pertama yang secara komprehensif menjamin hak-hak publik atas informasi. Kedua, secara komprehensif, Undang-Undang Keterbukaan Informasi Publik telah mengatur kewajiban badan/pejabat publik untuk memberikan akses informasi terbuka dan efisien kepada publik. Melalui Undang-Undang Keterbukaan Informasi Publik ini, kewajiban untuk memberikan informasi, dokumen dan data diintegrasikan sebagai bagian intern dari fungsi birokrasi pemerintahan, diperkuat dengan sanksi-sanksi yang tegas bagi pelanggarannya.

Ketiga, Undang-Undang Keterbukaan Informasi Publik mengatur klasifikasi informasi sedemikian rupa sehingga memberikan kepastian hukum tentang informasi-informasi apa saja yang wajib 
dibuka kepada public, dan informasi apa saja yang bisa dikecualikan dalam periode tertentu. Di sini, secara teoritis UndangUndang Keterbukaan Informasi Publik memberikan solusi bagi kalangan jurnalis, peneliti, dan masyarakat awam yang selama ini selalu menghadapi klaim rahasia negara, rahasia instansi atau rahasia jabatan ketika mendapatkan dokumen-dokumen di badan publik. Keempat, Undang-Undang Keterbukaan Informasi Publik telah melembagakan Komisi Informasi sebagai lembaga negara independen yang berperan sebagai lembaga penyelesaian sengketa akses informasi dan lembaga regulator di bawah Undang-Undang.

Urgensi dari adanya keterbukaan informasi bagi terwujudnya pemerintahan yang baik, sebagaimana diungkap Rajamuddin, karena hal tersebut akan memberikan dampak positif dalam hal pelaksanaan proses bernegara. Selain itu akan memberikan kontribusi besar kepada pelaksana negara dalam hal mempercepat terwujudnya negara hukum yang demokratis, karena: Pertama, keterbukaan informasi merupakan syarat utama melawan korupsi. Kedua, hak atas informasi adalah bagian dari Hak Asasi Manusia (HAM). Ketiga, hak publik atas informasi sebagai hak konstitusional setiap warga negara. Keempat, hak publik atas informasi sebagai perangkat politik mengontrol peneyelenggaraan pemerintahan.

Dari fakta di atas, dapat ditarik suatu hipotesa bahwa untuk mewujudkan pemerintahan yang bersih demi kemanfaatannya untuk orang banyak, kebebasan untuk mendapatkan informasi merupakan syarat kunci yang mesti dipenuhi oleh penyelenggara negara.

\section{METODE}

Tulisan ini merupakan hasil penelitian yang dilakukan dengan pendekatan kualitatif yang bertujuan untuk menggambarkan atau mendeskripsikan secara tepat sifat atau fenomena keterbukaan informasi public di Kota Malang dengan menggunakan Undangundang No. 14 tahun 2008 tentang Keterbukaan Informasi Publik yang dgambarkan secara sistimatis, faktual dan akurat sehingga dapat mengetahui hubungan kausalitas antara fenomena.

\section{KETERBUKAAN INFORMASI PUBLIK DALAM PRAKTEK TRANSPARANSI DI KOTA MALANG}

Pemerintah Kota Malang dalam menjalankan undang-undang No. 14 tahun 2008, praktek pelaksanaannya diberlakukan mulai 2010. Aturan-aturan melalui Peraturan Wali Kota (Perwali) No 50 tahun 2010 tentang Pedoman Pelayanan Informasi Publik merupakan komitmen tertulis dalam menjalankan amanah undang-undang. Pada Perwali ini diatur dan dijelaskan secara teknis tentang struktur PPID (Pejabat Pengelola Informasi dan Dokumentasi) di Pemerintah Kota Malang. PPID ini lah yang menjadi ujung tombak dari pelaksanaan undangundang No. 14 tahun 2008. PPID utama adalah ex officio Kepala Dinas Komunikasi dan Informasi (Kominfo). Lalu di bawahnya ada PPID pembantu yang dijabat oleh sekretaris OPD (Organisasi Perangkat Daerah). Sedangkan di kantor pusat adalah Kepala 
Bagian Hubungan Masyarakat (Kabag Humas).

Oleh sebab itu, berikut ini adalah bentuk pelaksanaan undang-undang No 14 tahun 2008 di Kota Malang. Pertama, pelaksanaan ketentuan pasal 2 undangundang 14 tahun 2008. Pada pasal ini menyebutkan bahwa setiap informasi publik harus bersifat terbuka, dan dapat diakses oleh setiap pengguna informasi publik. Untuk merealisasikan ketentuan ini Pemerintah Kota Malang sudah membuat website resmi. Website ini lah yang bisa diakses secara terbuka oleh siapa pun dengan cepat dan tepat waktu, biaya ringan dan cara sederhana. Untuk seluruh informasi dari badan publik di Pemerintah Kota Malang website resminya adalah www.malangkota.go.id. Selain itu, setiap OPD, badan, inspektorat-kantor dan satuan, dan juga di setiap kecamatan dan kelurahan juga mempunyai website resmi. Jika ditotal, secara keseluruhan website tersebut berjumlah 100. Dengan perincian, di lingkungan sekretariat daerah 9 website. Di lingkungan sekretariat DPRD Kota Malang 1 website. Di tingkat badan memiliki 8 website, di tingkat OPD/Dinas memiliki 15 website, termasuk Inspektorat, Kantor dan Satuan memiliki 4 website.

Selanjutnya setiap kecamatan dan setiap kelurahan punya website sendirisendiri. Lima kecamatan masing-masing satu website, dan 57 kelurahan masing-masing juga punya 1 website. Ditambah website induk yang dikelola Dinas Komunikasi dan Informasi www.malangkota.go.id. Jadi, total ada 100 website, dimana semuanya menggunakan sub-domain malangkota.go.id.
Dari 100 website tersebut, dianalisis secara acak, ditemukan bahwa sebanyak 24 website yang aktif selama Desember 2017. Website yang diupdate secara real time hanya website induk yakni www.malangkota.go.id. Sedangkan mayoritas website (15 website) tidak diupdate secara berkala.

Website milik DPRD Kota Malang saja sejak 30 Maret 2014 tidak diupdate. Di jajaran eksekutif, website milik Kantor Ketahanan Pangan juga tidak diupdate sejak Agustus 2016. Website milik Dinas Pekerjaan Umum, Perumahan dan Pengawasan Bangunan malah tidak bisa dibuka. Sedangkan website yang aktif diupdate secara berkala di antaranya milik Bagian Humas, Dinas Pendidikan, Badan Pengelola Keuangan dan Aset Daerah (BPKAD), dan Dinas Pendapatan Daerah yang telah berubah menjadi Badan Pelayanan Pajak Daerah (BPPD).

Di jajaran kecamatan dan kelurahan, dari 15 website yang dijadikan sebagai objek analisis, jumlah website yang tidak diupdate secara berkala hanya 11 web. Sedangkan yang diupdate secara berkala berjumlah 4 website. Di tingkat kecamatan yang tidak diupdate secara berkala adalah Kecamatan Kedungkandang, Kecamatan Lowokwaru, dan Kecamatan Sukun. Dari lima kecamatan yang ada di Kota Malang, website yang diupdate secara berkala hanya Kecamatan Klojen dan Blimbing. Sedangkan di tingkat kelurahan, dari 10 kelurahan yang dijadikan sampel, hanya dua website milik kelurahan yang diupdate secara berkala. Yakni Kelurahan Sawojajar dan Tlogo Mas. Sedangkan delapan kelurahan lain seperti Samaan, Kasin, Kedungkandang, Tasikmadu, Polehan, Purwantoro, Bakalan Krajan, dan 
Pisang Candi, websitenya tidak diupdate secara berkala. Rata-rata tidak diupdate sejak 2016.

Kemudian sejumlah 24 website di lingkungan Pemerintah Kota Malang itu dapat dikatakan bahwa dari sisi penyediaan media penyampai informasi publik, Pemerintah Kota Malang sudah cukup baik. Hal ini dapat dilihat dari keberadaan website yang dimiliki oleh setiap bagian, badan, OPD, kecamatan hingga kelurahan di lingkungan Pemerintah Kota Malang. Dengan keberadaan website itu, siapa pun bisa mengakses informasi publik dari setiap bagian, badan, OPD, kecamatan hingga kelurahan yang ada di lingkungan Pemerintah Kota Malang. Sayangnya hal ini tidak diimbangi dengan konsistensi dalam mengupdate secara berkala informasi publik seperti yang diharapkan Pasal 9 undang-undang No 14 tahun 2008. Pada ayat 1 pasal ini menyebutkan bahwa setiap badan publik wajib mengumumkan informasi publik secara berkala.Dan yang dimaksud berkala adalah paling singkat enam bulan sekali (ayat 3).

Tentang rendahnya tingkat kerajinan dalam mengupdate secara berkala informasi publik di website milik instansi di lingkungan Pemerintah Kota Malang ini juga diakui oleh aparatur di lingkungan Pemerintah Kota Malang yang menyebutkan bahwa kendala yang dialami oleh aparatur yang ditugaskan adalah kendala teknis, kekurangan sumberdaya manusia serta kekurangan personil dalam mengembangkan informasi berbasis teknologi.

Dorongan Semu dalam Menjalankan Fungsi Transfaransi di Era Digital
Dorongan keaktifan unit-unit organisasi/organisasi perangkat daerah dilingkungan Pemerintah Kota Malang dalam menjalankan fungsinya untuk menyampaikan informasi public di Kota Malang pada dasarnya diikuti dengan spirit lain, yakni reward yang diberikan oleh Walikota melalui kompetisi. Ketika kompetisi tidak dilaksanakan, semangat dalam menyampaikan informasi public melalui teknologi juga semakin menurun. Hal ini diakui oleh leading sector lembaga pemerintahan yang membidangi urusan teknologi dan informasi di Kota Malang.

Di lingkungan Pemerintah Kota Malang, Anugerah Inovasi dan Kreativitas Informasi Digital (AIKID) menjadi ajang bagi unit-unit dilingkungan Pemerintah Kota Malang menunjukkan keunggulannya dalam teknologi informasi. Oleh sebab itu, selama kompetisi dilaksanakan, keterbaruan informasi melalui media digital tetap terjaga. Namun saat ajang kompetisi tidak lagi dilaksanakan, spirit kompetisi tersebut juga ikut memudar. Hal inilah yang menjadikan website resmi pemerintahan dilingkungan Pemerintah Kota Malang tidak update sejak tahun 2016.

Ketekaitan antara ajang kompetisi dengan keaktifan media informasi public melalui website sangatlah erat. Hal ini dapat dilihat dari aspek-aspek penilaian yang dijadikan standar dalam kompetisi seperti: Pertama, tata kelola TIK (Teknologi, Informasi dan Komunikasi). Meliputi kebijakan (Undang-undang, Peraturan Daerah, Peraturan Walikota, Surat Keputusan, dan struktur organisasi), Renstra (rencana strategis), Infrastruktur (software, hardware, 
dan SDM), dan SOP/POS (Prosedur Operasional Standar). Kedua, website. Meliputi fitur (fasilitas pencarian, link, statistik, sitemap, navigasi), layanan (teknis, frekuensi update, kelengkapan informasi), inovasi (pemanfaatan multimedia, keragaman akses, dan media sosial), estetika (desain dan kesesuaian), dan interaktif (chating dan respons admin). Dan yang ketiga adalah polling yang meliputi pengunjung website dan pilihan user.

Setelah dilakukan penilaian, maka dipilihlah yang terbaik. Dan yang berhasil meraih predikat terbaik diberikan hadiah. Upaya ini bagus dilakukan untuk menstimulus instansi-instansi di lingkungan Pemerintah Kota Malang agar berlombalomba memberikan yang terbaik dalam hal penyediaan media penyampai informasi publik melalui website. Sayangnya, AIKID tak lagi dilakukan selama dua tahun terakhir (2016 dan 2017) karena terkendala anggaran.

Berdasarkan ketentuan Pasal 9 ayat 2, terutama poin $a, b$, dan $c$, informasi publik yang wajib diumumkan kepada publik secara berkala adalah informasi yang berkaitan dengan badan publik (poin a), informasi mengenai kegiatan dan kinerja badan publik terkait (poin b), dan informasi mengenai laporan keuangan (poin c). Jadi, dalam implementasi pelaksanaan amanah undangundang tersebut ditemukan bahwa "belum ada" website-website milik badan publik tersebut yang melaporkan secara berkala laporan keuangannya secara detail. Kalau pun ada keterkaitan dengan laporan keuangan, yang dilaporkan bukan lah laporan keuangan secara menyeluruh milik badan publik bersangkutan. Misalnya, di Badan Pengelola
Keuangan dan Aset Daerah (BPKAD), dilaporkan tentang daftar penerima dana hibah. Sementara laporan keuangan yang menjelaskan tentang kondisi keuangan dari BPKAD tidak dilaporkan secara detail. Sebenarnya pada website milik BPKAD ada laman khusus untuk melihat APBD Kota Malang. Tapi, laman khusus itu dilindungi dengan password. Sehingga tidak bisa diakses secara bebas dan mudah.

Di lingkungan Pemerintah Kota Malang, website yang mempublikasikan laporan keuangan secara detail, termasuk rincian perolehan pendapatan dari pajak adalah website milik Badan Pelayanan Pajak Daerah (BPPD). Sedangkan website milik kecamatan dan kelurahan yang diamati, tidak ada satu pun yang merinci tentang laporan keuangan.

Sementara itu, pelaksanaan Pasal 11 ayat 1 , terutama pada poin $b, c$ dan $d$. Mengacu pada ketentuan ini, bahwa badan publik wajib menyediakan informasi publik setiap saat, meliputi hasil keputusan badan publik dan pertimbangannya (poin b). Selanjutnya seluruh kebijakan yang ada, berikut dokumen pendukungnya (poin c). Lalu rencana kerja proyek, termasuk di dalamnya perkiraan pengeluaran tahunan badan public (poin $\mathrm{d}$ ). Informasi seperti dimaksud pada poin b, c, d ini lazimnya ada di dalam APBD. Dari hasil pengamatan penulis secara acak terhadap 24 website di lingkungan Pemerintah Kota Malang itu, belum ada data yang dipublikasikan seperti yang dimaksud pada Pasal 11 ayat 1 poin b, c dan d. Padahal, informasi-informasi tersebut sebenarnya cukup penting disampaikan kepada publik. 
Persoalan tidak adanya informasi di website-website di lingkungan Pemerintah Kota Malang seperti yang diatur dalam ketentuan Pasal 11 undang-undang No 14 tahun 2008 terutama pada poin b, c, d itu diakui oleh leading sector bidang teknologi informasi kota malang bahwa lagi-lagi terkendala dengan peroalan ketersediaan SDM (sumber daya manusia).

Ketentuan lainnya dalam amanah Undang-undang keterbukaan informasi public adalah tentang keberadaan BUMD (Badan Usaha Milik Daerah) milik Pemerintah Kota Malang yang harus diinformasikan secara berkala kepada publik, merujuk pada ketentuan yang ada dalam Pasal 14. Berdasarkan ketentuan Pasal 14 ini, BUMD wajib menyediakan informasi publik di antaranya: Informasi tentang nama-nama lengkap para pemegang saham, anggota direksi, dan anggota dewan komisaris perseroan. Informasi ini penting untuk melihat, apakah BUMD sudah dipegang atau dijalankan oleh orang-orang yang ahli dan kompeten.Informasi lainnya yang harus disediakan kepada publik adalah laporan tahunan, laporan keuangan, neraca laporan laba-rugi, dan laporan tanggung jawab sosial perusahaan yang telah diaudit.

Dari 24 website di lingkungan Pemerintah Kota Malang, juga belum ada yang mempublikasikan secara berkala dan secara detail tentang keberadaan BUMD. Termasuk di website milik Dinas Kominfo,. Karena tidak ada informasi tentang keberadaan BUMD, kondisinya dan kinerjanya di website, sehingga keberadaan BUMD menjadi tidak bisa dikontrol atau tidak bisa diawasi oleh publik. Karena tidak bisa diawasi oleh publik, maka sangat rawan terjadinya penyimpangan dan praktek maladministasi.

\section{KESIMPULAN}

Dari fakta yang diperoleh, keberadaan website sebagai media keterbukaan seperti yang diamanatkan uleh undang-undang maka diakhir tulisan ini dapat disimpulkan bahwa: Pertama, dari sisi keberadaan media penyampai informasi publik sebagai wujud dari pelaksanaan undang-undang No 14 tahun 2008 tentang Keterbukaan Informasi Publik, Pemerintah Kota Malang sudah melaksanakannya melalui pembuatan website. Ada 100 website yang telah dibuat di lingkungan Pemerintah Kota Malang.

Kedua, keberadaan website-website di lingkungan Pemerintah Kota Malang sebagai penyampai informasi publik masih belum maksimal dalam menjalankan ketentuan dalam undang-undang No 14 tahun 2008. Yang dipublikasikan kebanyakan sebatas hanya tentang seputar kegiatan dari badanbadan publik di lingkungan Pemerintah Kota Malang.Sedangkan hal-hal krusial dan penting yang seharusnya disampaikan kepada publik, tidak dipublikasikan secara berkala dan detail.Misalnya, laporan keuangan, APBD serta laporan tentang keberadaan BUMD.

Ketiga, tidak ada satu pun website di lingkungan Pemerintah Kota Malang yang mempublikasikan tentang keberadaan BUMD, seputar tentang kinerjanya, atau laporan keuangannya. Sehingga membuat BUMD menjadi sulit untuk diawasi.Ini bisa berakibat rawan terjadi penyelewengan. Baik penyelewengan keuangan atau pun penyelewengan jabatan. 
Keempat, penyebab belum maksimalnya dalam menjalankan ketentuan dalam undang-undang No 14 tahun 2008 di lingkungan Pemerintah Kota Malang, salah satu alasannya karena keterbatasan SDM dan keterbatasan anggaran. Padahal, masyarakat dan stakeholders memiliki hak untuk mengakses informasi mengenai jumlah anggaran yang dialokasikan untuk suatu kegiatan tertentu termasuk juga alasan yang melatarbelakanginya (Dwiyanto, 2005: 224). Masyarakat dan stakeholders perlu mengetahui seberapa besar pemerintah memberikan perhatian terhadap kepentingan dan kebutuhan masyarakat. Dengan memiliki akses terhadap informasi mengenai alokasi anggaran maka mereka dapat menilai seberapa banyak uang yang dimiliki pemerintah digunakan untuk memenuhi kebutuhan dan kepentingan masyarakat banyak. Masyarakat juga dapat mengetahui apakah pemerintah membelanjakan uangnya untuk kepentingan rakyat, atau hanya untuk kepentingan para pejabatnya.

Jika hak-hak masyarakat untuk mengetahui berbagai informasi publik ini dipenuhi secara maksimal oleh pemerintah, maka akan tercipta transparansi birokrasi. Transparansi menjadi salah satu ukuran penting dari good governance. Transparansi juga memiliki keterkaitan yang erat dengan akuntabilitas publik.Selain itu transparansi juga menjadi syarat utama pelaksanaan reformasi birokrasi. Governance dinilai baik atau buruk, salah satunya ditentukan oleh tingkat transparansi di dalam pemerintahannya (Dwiyanto, 2005: 226). Terdapat tiga indicator yang dapat dijakdikan sebagai alat ukur dalam transparansi public yaitu: 1]. Mengukur tingkat keterbukaan proses penyelenggaraan pelayanan public; 2]. dari tranparansi menunjuk pada seberapa mudah peraturan dan prosedur pelayanan dapat dipahami oleh pengguna dan stakeholders yang lain. Maksud dari "dipahami" di sini bukan hanya dalam artiliteral semata, tetapi juga makna di balik semua prosedur dan peraturan itu; dan 3]. Transparansi pelayanan adalah kemudahan untuk memperoleh informasi mengenai berbagai aspek penyelenggaraan pelayanan publik. Semakin mudah pengguna memperoleh informasi mengenai berbagai aspek penyelenggaraan pelayanan publik, semakin tinggi transparansi (Dwiyanto, 2005:236).

Dari paparan diatas, maka perlu didirikan Komisi Informasi di Kota Malang. Komisi Informasi mempunyai kewenangan, salah satunya membuat standar layanan informasi publik sesuai amanat undangundang No 14 tahun 2008. Di Jawa Timur, baru ada dua Komisi Informasi di tingkat kabupaten/kota yakni di Kabupaten Bangkalan dan Sampang.

Kota Malang sebagai kota yang dinamis, sebagai kota terbesar kedua di Jawa Timur setelah Surabaya, sudah selayaknya mempunyai Komisi Informasi. Ini untuk menjamin agar badan-badan publik di lingkungan Pemerintah Kota Malang melaksanakan prinsip transparansi sebagai prasayarat reformasi birokrasi melalui penerapan undang-undang No 14 tahun 2008.

Faktor political will dari kepala daerah sangat penting dalam hal pelaksanaan undang-undang No 14 tahun 2008 tentang Keterbukaan Informasi Publik. Dalam hal ini, 
Wali Kota Malang harus punya strong leadership agar di jajaran di bawahnya benarbenar melaksanakan prinsip-prinsip transparansi birokrasi melalui penerapan undang-undang No 14 tahun 2008.

\section{DAFTAR PUSTAKA}

Brinkerhoff, Derick, W, Crosby, Benjamin, L. 2002, Managing Policy Reform, Concepts and Tools for Decision Makers in Developing and Transitioning Countries., Kumarian Press, Inc, USA

Dwiyanto, Agus, 2005, Mewujudkan Good Governance Melalui Pelayanan Publik, Gadjah Mada University Press

Kooiman, Jan, 2003, Governing as Governance, Sage Publication

Komisi Informasi Provinsi Jawa Timur, 2015, Himpunan Peraturan PerUndangundangan Keterbukaan Informasi Publik, Pemerintah Provinsi Jawa Timur

Moleong, Lexy, J, 2001, Metodologi Penelitian Kualitatif, PT Remaja Rosdakarya, Bandung

Rajamuddin, A, 2012, Kebebasan Mendapatkan Informasi, Perspektif Hak Asasi Manusia Jurnal Al Risalah, Vol 12 No 2, hal. 200.

Santosa, Pandji, 2012, Administrasi Publik Teori dan Aplikasi Good Governance, PT Refika Aditama, Bandung

Thoha, Miftah, 2014, Birokrasi Pemerintah Indonesia di Era Reformasi, Kencana Prenadamedia Group, Jakarta. 